\title{
Marinoscillum gen. nov., a member of the family 'Flexibacteraceae', with Marinoscillum pacificum sp. nov. from a marine sponge and Marinoscillum furvescens nom. rev., comb. nov.
}

Correspondence Kae Kyoung Kwon kkkwon@kordi.re.kr

\author{
Hyun-Seok Seo, Kae Kyoung Kwon, Sung-Hyun Yang, Hee-Soon Lee, \\ Seung Seob Bae, Jung-Hyun Lee and Sang-Jin Kim
}

Marine Biotechnology Research Center, Korea Ocean Research and Development Institute, PO Box 29, Ansan 425-600, Republic of Korea

\begin{abstract}
A novel strain, designated MRN461 ${ }^{\top}$, was isolated from a marine sponge in Micronesia. The $16 \mathrm{~S}$ rRNA gene sequence of the isolate showed $95.6 \%$ similarity with that of 'Microscilla furvescens' IFO (now NBRC) 15994. Phylogenetic analysis revealed that the isolate and 'Microscilla furvescens' IFO 15994 formed a distinct phyletic line within the family 'Flexibacteraceae'. Cells of strain MRN461 ${ }^{\top}$ were Gram-negative, long filamentous rods, motile by gliding. Growth was observed at $15-40{ }^{\circ} \mathrm{C}$ (optimum, $33^{\circ} \mathrm{C}$ ), at $\mathrm{pH}$ 5.0-9.5 (optimum, $\mathrm{pH} 7.5$ ) and in the presence of $0.5-7.0 \%$ sea salts (optimum, $2.5 \%$ ). The major isoprenoid quinone was MK-7. The dominant fatty acids were summed feature 3 (comprising iso- $\mathrm{C}_{15: 0} 2-\mathrm{OH}$ and/or $\mathrm{C}_{16: 1} \omega 7 c ; 34.8 \%$ ), $\mathrm{C}_{16: 1} \omega 5 c(21.6 \%)$ and iso- $\mathrm{C}_{16: 1}(19.8 \%)$. The DNA G+C content was $41.5 \mathrm{~mol} \%$. On the basis of evidence from our polyphasic taxonomic study, strain MRN461 ${ }^{\top}$ is classified within a novel genus and species in the family 'Flexibacteraceae', for which the name Marinoscillum pacificum gen. nov., sp. nov. is proposed. The type strain of Marinoscillum pacificum is strain

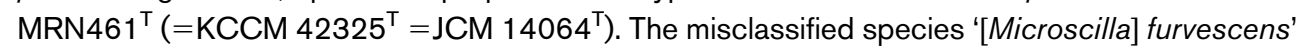
is transferred to the new genus as Marinoscillum furvescens (ex Lewin 1969) nom. rev., comb. nov., with LMG $13023^{\top}\left(=\mathrm{DSM} 4134^{\top}=\right.$ ATCC $23129^{\top}=$ NBRC $\left.15994^{\top}\right)$ as the type strain.
\end{abstract}

Although widely distributed in coastal marine ecosystems, the heterotrophic, Gram-negative bacteria, non-motile or motile by gliding, that belong to the phylum Bacteroidetes (previously Cytophaga-Flavobacterium-Bacteroides) have been poorly investigated (Nedashkovskaya et al., 2003). On the basis of $16 \mathrm{~S}$ rRNA gene sequence analysis, Nakagawa et al. (2002) demonstrated the considerable heterogeneity of strains previously allocated to the genera Flexibacter, Microscilla and Flexithrix. They proposed that all Flexibacter and Microscilla species except for the type species Flexibacter flexilis and Microscilla marina should be reclassified on the basis of their genomic and phenotypic characteristics. For instance, [Flexibacter] sancti, [Flexibacter] filiformis and [Flexibacter] japonensis were transferred to the genus Chitinophaga (Kämpfer et al., 2006) and '[Microscilla] arenaria' was reclassified as Flammeovirga arenaria (Takahashi et al., 2006). However, [Flexibacter] tractuosus, '[Microscilla] furvescens' and

The GenBank/EMBL/DDBJ accession number for the 16S rRNA gene sequence of strain MRN461 $1^{\top}$ is DQ660388.

A table listing differentiating characteristics of the two Marinoscillum species is available as supplementary material with the online version of this paper.
'[Microscilla] sericea' have not yet been reclassified and remain incorrectly classified. In the present study, we report the results of a polyphasic taxonomic investigation of the novel strain MRN461 ${ }^{\mathrm{T}}$ isolated from a marine sponge. The isolate represents a novel genus in the family 'Flexibacteraceae' together with '[Microscilla] furvescens' (Lewin, 1969; Lewin \& Lounsbery, 1969).

Strain MRN461 ${ }^{\mathrm{T}}$ was isolated from an unidentified marine sponge inhabiting the coast of the tropical Weno Island, Chuuk State, Federated States of Micronesia. A small piece of sponge was homogenized, diluted with sterile seawater and spread on marine agar 2216 (MA; Difco). Inoculated plates were cultivated at $25{ }^{\circ} \mathrm{C}$ for 2 days and morphologically distinct colonies were purified. Strain MRN461 ${ }^{\mathrm{T}}$ and '[Microscilla] furvescens' LMG 13023 were cultivated at $25{ }^{\circ} \mathrm{C}$ on MA for biochemical and physiological characterization and stored at $-80{ }^{\circ} \mathrm{C}$ in marine broth (MB; Difco) supplemented with $20 \%$ (v/v) glycerol (Bae et al., 2007).

The 16S rRNA gene was amplified by direct PCR and sequenced using an ABI 3100 automatic DNA sequencer according to the manufacturer's instructions. Comparison of the 16S rRNA gene sequence with sequences retrieved 
from GenBank and phylogenetic analyses were conducted according to the procedure described by Kwon et al. (2005). The 16S rRNA gene sequence of the isolate was a continuous stretch of $1495 \mathrm{bp}$, and a total of 1321 unambiguously aligned positions were compared with closely related sequences. Strain MRN461 ${ }^{\mathrm{T}}$ showed $95.6 \%$ $16 \mathrm{~S}$ rRNA gene sequence similarity with '[Microscilla] furvescens' IFO (now NBRC) 15994 (=LMG 13023), 90.0-91.5\% with members of the genera Fabibacter and Roseivirga and $<90 \%$ sequence similarity with all other related taxa. The neighbour-joining phylogenetic tree confirmed that strain MRN461 ${ }^{\mathrm{T}}$ and '[Microscilla] furvescens' IFO 15994 occupy a distinct phyletic line, but the relationship with other species was not supported by bootstrap analysis (Fig. 1). The maximum-likelihood tree showed essentially the same topology (data not shown). Consequently, strains MRN461 ${ }^{\mathrm{T}}$ and '[Microscilla] furvescens' IFO 15994 represent two different species in a novel genus.

As determined by HPLC using a Symmetry reversed-phase $\mathrm{C}_{18}$ column (Stackebrandt \& Liesack, 1993), the DNA $\mathrm{G}+\mathrm{C}$ content of strain $\mathrm{MRN} 461^{\mathrm{T}}$ was $41.5 \mathrm{~mol} \%$, a value in line with that reported for '[Microscilla] furvescens' LMG 13023 (44 mol\%; Lewin, 1969).

Analysis of the fatty acid methyl esters of strain MRN461 ${ }^{\mathrm{T}}$ and '[Microscilla] furvescens' LMG 13023 was carried out by using the MIDI/Hewlett Packard Microbial Identification System (MIS) (Sasser, 1990) according to the manufacturer's instructions using cells grown on MA for 3 days at $25{ }^{\circ} \mathrm{C}$. The major fatty acids of strain $\mathrm{MRN} 461^{\mathrm{T}}$ were summed feature 3 (comprising iso- $\mathrm{C}_{15: 0} 2-\mathrm{OH}$ and/or $\left.\mathrm{C}_{16: 1} \omega 7 c ; 34.8 \%\right), \mathrm{C}_{16: 1} \omega 5 c(21.6 \%)$ and iso- $\mathrm{C}_{15: 0}$ $(19.8 \%)$ and those of '[Microsilla] furvescens' LMG 13023 were $\mathrm{C}_{16: 1} \omega 5 c(28.5 \%)$, summed feature 3 $(22.2 \%)$ and iso- $\mathrm{C}_{15: 1} \mathrm{G}(8.5 \%)$ (Table 1$)$. The fatty acid profiles of the two strains were similar but differed in the respective proportions of iso- $\mathrm{C}_{15: 0}$ and iso- $\mathrm{C}_{15: 1} \mathrm{G}$. The proportions of $\mathrm{C}_{16: 1} \omega 5 c$ and summed feature 3 in the two strains distinguished them from members of related genera. In accordance with the other members of the family 'Flexibacteraceae', the major respiratory quinone of both strains was MK-7, as determined by HPLC analysis according to the method of Collins (1985).

Unless otherwise stated, the phenotypic characterization of strain MRN461 ${ }^{\mathrm{T}}$ and '[Microscilla] furvescens' LMG 13023 was conducted according to previously described methods (Bae et al., 2005; Lee et al., 2008; Sohn et al., 2004). The presence of $\mathrm{NaCl}$ alone in the medium did not support growth of strain MRN461 ${ }^{\mathrm{T}}$ or '[Microscilla] furvescens' LMG 13023. We therefore tested the requirement for three other seawater components: $\mathrm{CaCl}_{2}, \mathrm{KCl}$ and $\mathrm{MgCl}_{2}$. All combinations of these components at concentrations of $0.18 \% \quad \mathrm{CaCl}_{2} \cdot 2 \mathrm{H}_{2} \mathrm{O}, \quad 0.055 \% \quad \mathrm{KCl}$ and $0.59 \%$ $\mathrm{MgCl}_{2} \cdot 6 \mathrm{H}_{2} \mathrm{O}$ were added to modified ZoBell 2216e medium containing $5 \mathrm{~g}$ yeast extract, $1 \mathrm{~g}$ peptone, $30 \mathrm{~g}$ $\mathrm{NaCl}$ and $0.01 \mathrm{~g} \mathrm{FePO}_{4}$ per litre of distilled water. A commercial sea salts preparation (Sigma) was also used to test the salt tolerance range of strain $M R N 461^{\mathrm{T}}$ and '[Microscilla] furvescens' LMG 13023. The degradation of starch and casein was tested according to Smibert \& Krieg (1994). Bacterial suspensions used to inoculate the API 20E and API 20NE (bioMérieux) and Microlog GN2 (Biolog) systems were prepared in a $2.5 \%$ sea salt solution. The physiological, biochemical and morphological characteristics of strain MRN461 ${ }^{\mathrm{T}}$ and '[Microscilla] furvescens' LMG 13023 are given below in the genus and species descriptions, in Table 2 and in Supplementary Table S1 (available in IJSEM Online).

Strain MRN461 ${ }^{\mathrm{T}}$ and '[Microscilla] furvescens' LMG 13023 shared many characteristics with members of closely related genera within the family 'Flexibacteraceae' such as the presence of MK-7 as the major respiratory quinone, the presence of oxidase and catalase activities and the absence of flexirubin-type pigments. However, the results of the phylogenetic analysis and the level of 16S rRNA gene sequence similarity as well as differences in cell morpho-

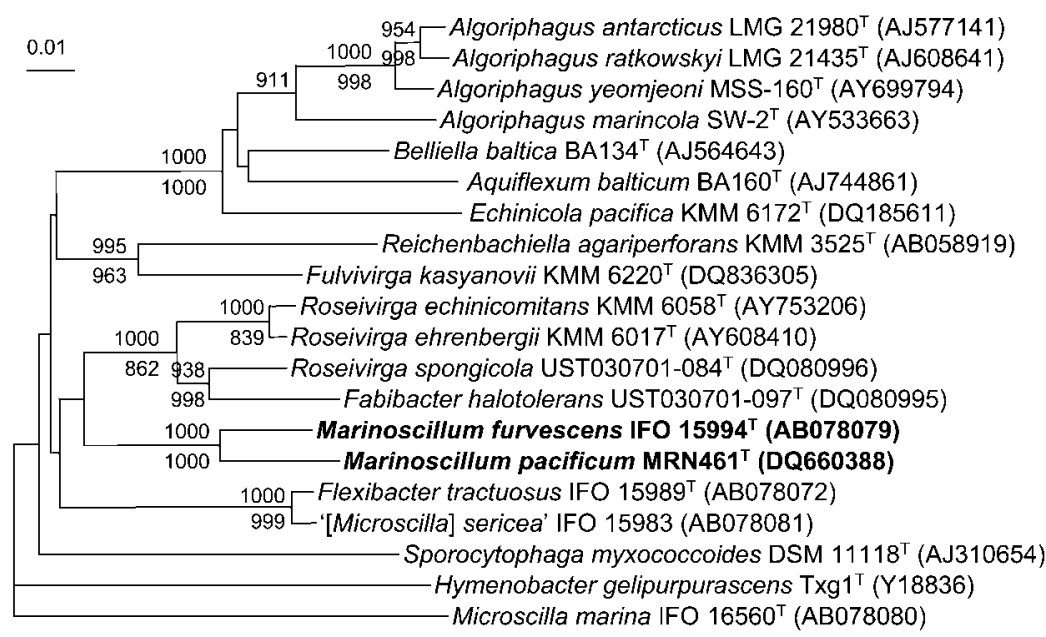

Fig. 1. Rooted neighbour-joining tree based on nearly complete 16S rRNA gene sequences (1323 unambiguously aligned positions) showing relationships between strain MRN461 ${ }^{\top}$ and '[Microscilla] furvescens' IFO 15994 (=LMG 13023) and related taxa. The 16S rRNA gene sequences of Hymenobacter gelipurpurascens $\operatorname{Txg}^{\top}{ }^{\top}$ and Microscilla marina IFO $16560^{\top}$ served as an outgroup. Bootstrap values $>700$ of 1000 replicates are shown (upper, Jukes-Cantor neighbour-joining; lower, maximum-likelihood-parsimony). Bar, 0.01 substitutions per nucleotide position. 
Table 1. Fatty acid compositions of strain $M R N 461^{\top}$ and '[Microscilla] furvescens' LMG 13023 and related taxa in the family 'Flexibacteraceae'

Taxa: 1, strain MRN461 ${ }^{\mathrm{T}}$; 2, '[Microscilla] furvescens' LMG 13023; 3, Fabibacter halotolerans UST030701-097 ${ }^{\mathrm{T}}$; 4, genus Roseivirga (three species). Data were taken from this study, Lau et al. (2006), Nedashkovskaya et al. (2005a, 2005b) and Yoon et al. (2005). Values are percentages of total fatty acids. -, Not detected; tr, traces $(<1 \%)$; ECL, equivalent chain-length. Fatty acids amounting to $<0.5 \%$ of the total fatty acids in all strains are not shown. Strain MRN461 ${ }^{\mathrm{T}}$ and '[Microscilla] furvescens' LMG 13023 were grown on MA for 3 days at $25{ }^{\circ} \mathrm{C}$; Fabibacter and Roseivirga strains were grown under different culture conditions.

\begin{tabular}{|c|c|c|c|c|}
\hline Fatty acid & 1 & 2 & 3 & 4 \\
\hline \multicolumn{5}{|l|}{ Straight-chain } \\
\hline $\mathrm{C}_{14: 0}$ & 1.5 & 1.1 & - & - \\
\hline $\mathrm{C}_{15: 0}$ & $\operatorname{tr}$ & 0.9 & - & - \\
\hline $\mathrm{C}_{16: 0}$ & 2.6 & 3.5 & - & - \\
\hline \multicolumn{5}{|l|}{ Branched } \\
\hline iso- $\mathrm{C}_{13: 0}$ & - & - & 1.6 & $0.7-5.2$ \\
\hline iso- $\mathrm{C}_{14: 0}$ & - & - & 4.7 & 1.9 \\
\hline iso- $\mathrm{C}_{15: 0}$ & 19.8 & 8.5 & 18.3 & $18.6-33.5$ \\
\hline iso- $\mathrm{C}_{15: 1}$ & - & - & 14.2 & $12.5-20.2$ \\
\hline iso- $\mathrm{C}_{15: 1} \mathrm{G}$ & $\operatorname{tr}$ & 3.2 & - & - \\
\hline iso- $\mathrm{C}_{16: 0}$ & 1.9 & 3.2 & 1.2 & $1.2-2.0$ \\
\hline iso- $\mathrm{C}_{16: 1}$ & - & - & 1.2 & 2.0 \\
\hline iso- $\mathrm{C}_{17: 0}$ & $\operatorname{tr}$ & 1.0 & 0.5 & 1.0 \\
\hline anteiso- $\mathrm{C}_{15: 0}$ & - & - & 2.5 & $2.4-13.1$ \\
\hline anteiso- $\mathrm{C}_{15: 1}$ & - & - & $\operatorname{tr}$ & $1.8-2.4$ \\
\hline \multicolumn{5}{|l|}{ Unsaturated } \\
\hline $\mathrm{C}_{16: 1} \omega 5 c$ & 21.6 & 28.5 & - & - \\
\hline $\mathrm{C}_{17: 1} \omega 6$ & $\operatorname{tr}$ & 1.8 & - & - \\
\hline iso- $\mathrm{C}_{17: 1} \omega 9 c$ & - & - & - & $1.1-10.1$ \\
\hline \multicolumn{5}{|l|}{ Hydroxy } \\
\hline $\mathrm{C}_{14: 0} 2-\mathrm{OH}$ & 3.9 & 2.6 & - & - \\
\hline $\mathrm{C}_{15: 0} 2-\mathrm{OH}$ & $\operatorname{tr}$ & 1.5 & 1.9 & 3.2 \\
\hline $\mathrm{C}_{16: 0} 2-\mathrm{OH}$ & $\operatorname{tr}$ & 1.2 & - & - \\
\hline $\mathrm{C}_{17: 0} 2-\mathrm{OH}$ & - & - & 1.3 & $2.0-10.1$ \\
\hline $\mathrm{C}_{15: 0} 3-\mathrm{OH}$ & - & - & 1.3 & - \\
\hline $\mathrm{C}_{16: 0} 3-\mathrm{OH}$ & 1.2 & 1.9 & 1.2 & $1.6-1.8$ \\
\hline $\mathrm{C}_{17: 0} 3-\mathrm{OH}$ & $\operatorname{tr}$ & 1.0 & - & - \\
\hline iso- $\mathrm{C}_{14: 0} 3-\mathrm{OH}$ & - & - & 1.1 & - \\
\hline iso- $\mathrm{C}_{15: 0} 3-\mathrm{OH}$ & - & - & 12.5 & $3.0-5.6$ \\
\hline iso- $\mathrm{C}_{16: 0} 3-\mathrm{OH}$ & $\operatorname{tr}$ & 1.3 & 12.7 & $2.0-10.1$ \\
\hline iso- $\mathrm{C}_{17: 0} 3-\mathrm{OH}$ & 4.1 & 9.8 & 9.3 & $7.7-18.3$ \\
\hline \multicolumn{5}{|l|}{ Summed features ${ }^{*}$} \\
\hline 3 & 34.8 & 22.2 & 13.7 & $1.0-5.5$ \\
\hline 4 & $\operatorname{tr}$ & 1.0 & - & - \\
\hline Unknown ECL 14.959 & 1.3 & 1.1 & - & - \\
\hline
\end{tabular}

* Summed features represent groups of two or three fatty acids that could not be separated by GLC with the MIDI system. Summed feature 3 contained iso- $\mathrm{C}_{15: 0}$ 2-OH and/or $\mathrm{C}_{16: 1} \omega 7 c$. Summed feature 4 contained anteiso- $\mathrm{C}_{17: 1} \mathrm{~B}$ and/or iso- $\mathrm{C}_{17: 1} \mathrm{I}$. logy and in degradation ability for some high-molecularmass compounds distinguished the two strains from other members of the family 'Flexibacteraceae' and suggested that they represent two different species in a novel genus (Fig. 1, Table 2 and Supplementary Table S1). Consequently, strain MRN461 ${ }^{\mathrm{T}}$ and '[Microscilla] furvescens' LMG 13023 should be classified in a new genus in the family 'Flexibacteraceae', for which the name Marinoscillum gen. nov. is proposed. The novel species Marinoscillum pacificus gen. nov., sp. nov. and Marinoscillum furvescens nom. rev., comb. nov. are proposed to accommodate strain $\mathrm{MRN} 461^{\mathrm{T}}$ and '[Microscilla] furvescens' LMG 13023, respectively.

\section{Description of Marinoscillum gen. nov.}

Marinoscillum [Ma.ri.no.scil'lum. L. adj. marinus marine; L. neut. n. oscillum a swing; N.L. neut. n. Marinoscillum a marine swing(-like organism)].

Cells are aerobic, Gram-negative, flexible thread-like rods and motile by gliding. The cell mass is orange- or apricotcoloured. Mesophilic. Oxidase and catalase activities are present. The dominant respiratory quinone is MK-7 and the dominant fatty acids are $\mathrm{C}_{16: 1} \omega 5 c$ and summed feature 3 (comprising iso- $\mathrm{C}_{15: 0} 2-\mathrm{OH}$ and/or $\mathrm{C}_{16: 1} \omega 7 c$ ). The DNA $\mathrm{G}+\mathrm{C}$ content is $41-44 \mathrm{~mol} \%$. As determined by $16 \mathrm{~S}$ rRNA gene sequence analysis, the genus is a member of the family 'Flexibacteraceae' in the order 'Sphingobacteriales'. The type species is Marinoscillum pacificum.

\section{Description of Marinoscillum pacificum sp. nov.}

Marinoscillum pacificum (pa.ci'fi.cum. L. neut. adj. pacificum pacific, used to refer to the Pacific Ocean).

In addition to the description of the genus, the following properties are displayed. Cells are usually $0.2-0.5 \mu \mathrm{m}$ in diameter and 10 to $>100 \mu \mathrm{m}$ in length. Cells form apricotcoloured colonies on MA. Growth occurs at $15-40{ }^{\circ} \mathrm{C}$ (optimum, $33{ }^{\circ} \mathrm{C}$ ), at $\mathrm{pH}$ 5-9.5 (optimum, $\mathrm{pH} 7.5$ ) and in the presence of $0.5-7.0 \%(\mathrm{w} / \mathrm{v})$ sea salts (optimum, $2.5 \%$ ). Nitrate is not reduced to nitrite. Agar, starch and urea are not hydrolysed. $\mathrm{H}_{2} \mathrm{~S}$ is not produced. Requires $\mathrm{Na}^{+}$and $\mathrm{Mg}^{2+}$ ions for growth. In the API 20E and 20NE systems, $\beta$-glucosidase and tryptophan deaminase activities are present, but protease (gelatin hydrolysis) and urease activities are absent. Acid is not produced from glucose. In the Microlog GN2 microplate, $\alpha$-cyclodextrin, dextrin, L-arabinose, D-fructose, lactulose, maltose, D-galactose, Dmannose, melibiose, methyl $\beta$-D-glucoside, sucrose, glucuronamide, L-alanine, L-alanyl glycine, glucose 1-phosphate, cis-aconitic acid, citric acid, $\alpha$-ketobutyric acid, $\alpha$ ketoglutaric acid, DL-lactic acid, succinic acid, succinamic acid, L-glutamic acid, glycyl L-glutamic acid, L-pyroglutamic acid, cellobiose, gentiobiose, $\alpha$-D-lactose, raffinose, Lrhamnose, D-sorbitol, trehalose, turanose, hydroxy-L-proline, L-proline, L-fucose, D-galacturonic acid, L-aspartic acid, $\gamma$-aminobutyric acid and D-mannitol are utilized. The other substrates in the Microlog GN2 microplate are not 
Table 2. Differential characteristics of strain MRN461 ${ }^{\top}$ and '[Microscilla] furvescens' LMG 13023 and related taxa in the family 'Flexibacteraceae'

Taxa: 1, strain MRN461 ${ }^{\mathrm{T}}$; 2, '[Microscilla] furvescens' LMG 13023; 3, Fabibacter halotolerans UST030701-097' ; , genus Roseivirga (three species). Data were taken from this study, Lewin (1969), Lau et al. (2006), Nedashkovskaya et al. (2003, 2005a, b, 2008) and Yoon et al. (2005). +, Positive reaction; -, negative reaction; $\mathrm{v}$, variable; $(+)$, weakly positive; All taxa are positive for oxidase and catalase activities and possess MK-7 as the major respiratory quinone. All taxa are negative for $\mathrm{H}_{2} \mathrm{~S}$ production, nitrate reduction, degradation of agar, cellulose, chitin and urea and production of flexirubin-type pigments.

\begin{tabular}{|c|c|c|c|c|}
\hline Characteristic & 1 & 2 & 3 & 4 \\
\hline Pigmentation & Apricot & Orange & Pink & Orange/pink \\
\hline Temperature range for growth $\left({ }^{\circ} \mathrm{C}\right)$ & $15-40$ & $15-45$ & $12-30$ & $4-44$ \\
\hline $\mathrm{NaCl}$ range for growth (\%) & $0.4-5.4$ & $0.4-9.3$ & $0-12.0$ & $0-16.0$ \\
\hline \multicolumn{5}{|l|}{ Hydrolysis of: } \\
\hline Gelatin & - & + & - & + \\
\hline DNA & - & + & + & $\mathrm{V}$ \\
\hline Tween 80 & - & - & + & $\mathrm{V}$ \\
\hline \multicolumn{5}{|l|}{ Production of: } \\
\hline Indole & + & - & - & - \\
\hline Acetoin & + & - & + & $\mathrm{v}$ \\
\hline D-Mannose & + & + & - & - \\
\hline Mannitol & + & - & - & - \\
\hline Sorbitol & + & - & - & - \\
\hline DNA G + C content $(\mathrm{mol} \%)$ & 41.5 & 44 & 42.5 & $40.1-43.7$ \\
\hline
\end{tabular}

utilized. The dominant fatty acids are summed feature 3 (comprising iso- $\mathrm{C}_{15: 0} 2-\mathrm{OH}$ and/or $\mathrm{C}_{16: 1} \omega 7 c$ ), $\mathrm{C}_{16: 1} \omega 5 c$, iso- $\mathrm{C}_{15: 0}$ and iso- $\mathrm{C}_{17: 0}$ 3-OH. The full fatty acid composition is given in Table 1 . The DNA G+C content of the type strain is $41.5 \mathrm{~mol} \%$.

The type strain is MRN461 ${ }^{\mathrm{T}}\left(=\mathrm{KCCM} 42325^{\mathrm{T}}=\mathrm{JCM}\right.$ $14064^{\mathrm{T}}$ ), isolated from an unidentified marine sponge near the tropical Weno Island, Chuuk State, Federated States of Micronesia.

\section{Description of Marinoscillum furvescens (ex Lewin 1969) nom. rev., comb. nov.}

Marinoscillum furvescens (fur.ves'cens. L. adj. furvus pitch black, dark; L. part. adj. furvescens growing dark, dusky).

Basonym: 'Microscilla furvescens' Lewin 1969.

In addition to the descriptions of the genus and of '[Microscilla] furvescens' (Lewin, 1969), the following properties are displayed. Cells are usually $0.2-0.5 \mu \mathrm{m}$ in diameter and 10 to $>100 \mu \mathrm{m}$ in length. Cells form orangecoloured colonies on MA. Growth occurs at $15-45^{\circ} \mathrm{C}$ (optimum, $33.5^{\circ} \mathrm{C}$ ), at $\mathrm{pH}$ 6.5-9 (optimum, $\mathrm{pH} 7-7.5$ ) and in the presence of $0.5-12 \%(\mathrm{w} / \mathrm{v})$ sea salts (optimum,
$2.5 \%)$. Nitrate is not reduced to nitrite. Agar, starch and urea are not hydrolysed. $\mathrm{H}_{2} \mathrm{~S}$ is not produced. Requires $\mathrm{Na}^{+}$and either $\mathrm{Mg}^{2+}$ or $\mathrm{Ca}^{2+}$ ions for growth. In the API $20 \mathrm{E}$ and 20NE systems, $\beta$-glucosidase and protease (gelatin hydrolysis) activities are present, but urease activity is absent. Indole is not produced. Acid is not produced from glucose. In the Microlog GN2 microplate, $\alpha$-cyclodextrin, dextrin, L-arabinose, D-fructose, lactulose, maltose, Dgalactose, D-mannose, melibiose, methyl $\beta$-D-glucoside, sucrose, glucuronamide, L-alanine, L-alanyl glycine, glucose 1-phosphate, cis-aconitic acid, citric acid, $\alpha$-ketobutyric acid, $\alpha$-ketoglutaric acid, DL-lactic acid, succinic acid, succinamic acid, L-glutamic acid, glycyl L-glutamic acid, L-pyroglutamic acid, $\mathrm{N}$-acetyl-D-glucosamine, erythritol, myo-inositol, D-psicose, methyl pyruvate, L-serine, alaninamide, L-asparagine, L-threonine, inosine, DL- $\alpha$-glycerol phosphate, acetic acid, D-gluconic acid, $\beta$-hydroxybutyric acid, propionic acid, $p$-hydroxyphenylacetic acid, $\alpha$-ketovaleric acid and D-saccharic acid are utilized. The other substrates in the Microlog GN2 microplate are not utilized. The dominant fatty acids are $\mathrm{C}_{16: 1} \omega 5 c$, summed feature 3 (comprising iso- $\mathrm{C}_{15: 0} 2-\mathrm{OH}$ and/or $\mathrm{C}_{16: 1} \omega 7 c$ ), iso- $\mathrm{C}_{17: 0}$ $3-\mathrm{OH}$ and iso- $\mathrm{C}_{15: 1}$. The full fatty acid composition is given in Table 1 . The DNA G $+\mathrm{C}$ content of the type strain is $44 \mathrm{~mol} \%$. 
The type strain is LMG $13023^{\mathrm{T}}\left(=\mathrm{DSM} 4134^{\mathrm{T}}=\right.$ ATCC $23129^{\mathrm{T}}=$ NBRC $15994^{\mathrm{T}}$ ), isolated from sand in Samoa.

\section{Note added in proof}

According to Ludwig et al. (2008), the genera Fabibacter, Reichenbachiella and Roseivirga are members of the family 'Flammeovirgaceae'. It is therefore likely that the new genus Marinoscillum is also a member of the 'Flammeovirgaceae' rather than the 'Flexibacteraceae'.

\section{Acknowledgements}

This work was supported by the Marine \& Extreme Genome Research Center Program of the Ministry of Land, Transport and Maritime Affairs, Korea, and KORDI (PP00760).

\section{References}

Bae, S. S., Lee, J.-H. \& Kim, S.-J. (2005). Bacillus alveayuensis sp. nov., a thermophilic bacterium isolated from deep-sea sediments of the Ayu Trough. Int J Syst Evol Microbiol 55, 1211-1215.

Bae, S. S., Kwon, K. K., Yang, S.-H., Lee, H.-S., Kim, S.-J. \& Lee, J. H. (2007). Flagellimonas eckloniae gen. nov., sp. nov., a mesophilic marine bacterium of the family Flavobacteriaceae, isolated from the rhizosphere of Ecklonia kurome. Int J Syst Evol Microbiol 57, 10501054.

Collins, M. D. (1985). Isoprenoid quinone analysis in classification and identification. In Chemical Methods in Bacterial Systematics, pp. 267-287. Edited by M. Goodfellow \& D. E. Minnikin. London: Academic Press.

Kämpfer, P., Young, C. C., Sridhar, K. R., Arun, A. B., Lai, W. A., Shen, F. T. \& Rekha, P. D. (2006). Transfer of [Flexibacter] sancti, [Flexibacter] filiformis, [Flexibacter] japonensis and [Cytophaga] arvensicola to the genus Chitinophaga and description of Chitinophaga skermanii sp. nov. Int J Syst Evol Microbiol 56, 2223-2228.

Kwon, K. K., Lee, H.-S., Yang, S.-H. \& Kim, S.-J. (2005). Kordiimonas gwangyangensis gen. nov., sp. nov., a marine bacterium isolated from marine sediments that forms a distinct phyletic lineage (Kordiimonadales ord. nov.) in the 'Alphaproteobacteria'. Int J Syst Evol Microbiol 55, 2033-2037.

Lau, S. C. K., Tsoi, M. M. Y., Li, X., Plakhotnikova, I., Dobretsov, S., Wu, M., Wong, P.-K., Pawlik, J. R. \& Qian, P.-Y. (2006). Description of Fabibacter halotolerans gen. nov., sp. nov. and Roseivirga spongicola sp. nov., and reclassification of [Marinicola] seohaensis as Roseivirga seohaensis comb. nov. Int J Syst Evol Microbiol 56, 1059-1065.

Lee, H.-S., Kwon, K. K., Yang, S.-H., Bae, S. S., Park, C. H., Kim, S.-J. \& Lee, J.-H. (2008). Description of Croceitalea gen. nov. in the family Flavobacteriaceae with two species, Croceitalea eckloniae sp. nov. and Croceitalea dokdonensis sp. nov., isolated from the rhizosphere of the marine alga Ecklonia kurome. Int J Syst Evol Microbiol 58, 2505-2510.
Lewin, R. A. (1969). A classification of flexibacteria. J Gen Microbiol 58, 189-206.

Lewin, R. A. \& Lounsbery, D. M. (1969). Isolation, cultivation and characterization of flexibacteria. J Gen Microbiol 58, 145-170.

Ludwig, W., Euzéby, J. \& Whitman, W. B. (2008). Draft taxonomic outline of the Bacteroidetes, Planctomycetes, Chlamydiae, Spirochaetes, Fibrobacteres, Fusobacteria, Acidobacteria, Verrucomicrobia, Dictyoglomi, and Gemmatimonadetes. http://www.bergeys.org/outlines/ Bergeys_Vol_4_Outline.pdf

Nakagawa, Y., Sakane, T., Suzuki, M. \& Hatano, K. (2002). Phylogenetic structure of the genera Flexibacter, Flexithrix, and Microscilla deduced from 16S rRNA sequence analysis. J Gen Appl Microbiol 48, 155-165.

Nedashkovskaya, O. I., Suzuki, M., Vysotskii, M. V. \& Mikhailov, V. V. (2003). Reichenbachia agariperforans gen. nov., sp. nov., a novel marine bacterium in the phylum Cytophaga-FlavobacteriumBacteroides. Int J Syst Evol Microbiol 53, 81-85.

Nedashkovskaya, O. I., Kim, S. B., Lee, D. H., Lysenko, A. M., Shevchenko, L. S., Frolova, G. M., Mikhailov, V. V., Lee, K. H. \& Bae, K. S. (2005a). Roseivirga ehrenbergii gen. nov., sp. nov., a novel marine bacterium of the phylum 'Bacteroidetes' isolated from the green alga Ulva fenestrata. Int J Syst Evol Microbiol 55, 231-234.

Nedashkovskaya, O. I., Kim, S. B., Lysenko, A. M., Park, M. S., Mikhailov, V. V., Bae, K. S. \& Park, H. Y. (2005b). Roseivirga echinicomitans sp. nov., a novel marine bacterium isolated from the sea urchin Strongylocentrotus intermedius, and emended description of the genus Roseivirga. Int J Syst Evol Microbiol 55, 1797-1800.

Nedashkovskaya, O. I., Kim, S. B., Lysenko, A. M., Kalinovskaya, N. I. \& Mikhailov, V. V. (2008). Reclassification of Roseivirga seohaensis (Yoon et al. 2005) Lau et al. 2006 as a later synonym of Roseivirga ehrenbergii Nedashkovskaya et al. 2005 and emendation of the species description. Int J Syst Evol Microbiol 58, 1194-1197.

Sasser, M. (1990). Identification of bacteria by gas chromatography of cellular fatty acids, MIDI Technical Note 101. Newark, DE: MIDI Inc.

Smibert, R. M. \& Krieg, N. R. (1994). Phenotypic characterization. In Methods for General and Molecular Bacteriology, pp. 607-654. Edited by P. Gerhardt, R. G. E. Murray, W. A. Wood \& N. R. Krieg. Washington, DC: American Society for Microbiology.

Sohn, J. H., Kwon, K. K., Kang, J.-H., Jung, H.-B. \& Kim, S.-J. (2004). Novosphingobium pentaromativorans sp. nov., a high-molecular-mass polycyclic aromatic hydrocarbon-degrading bacterium isolated from estuarine sediment. Int J Syst Evol Microbiol 54, 1483-1487.

Stackebrandt, E. \& Liesack, W. (1993). Nucleic acids and classification. In Handbook of New Bacterial Systematics, pp. 152-189. Edited by M. Goodfellow \& A. G. O’Donnell. London: Academic Press.

Takahashi, M., Suzuki, K. \& Nakagawa, Y. (2006). Emendation of the genus Flammeovirga and Flammeovirga aprica with the proposal of Flammeovirga arenaria nom. rev., comb. nov. and Flammeovirga yaeyamensis sp. nov. Int J Syst Evol Microbiol 56, 2095-2100.

Yoon, J.-H., Kang, S.-J., Lee, C.-H. \& Oh, T.-K. (2005). Marinicola seohaensis gen. nov., sp. nov., isolated from sea water of the Yellow Sea, Korea. Int J Syst Evol Microbiol 55, 859-863. 